\title{
SHODHANA DECREASES NOOTROPIC ACTIVITY OF SEMECARPUS ANACARDIUM
}

\author{
MISHRA SK, ROUT K, PRUSTY SK, PRATAP KUMAR SAHU*
}

Department of Pharmacology, School of Pharmaceutical Sciences, Siksha '0' Anusandhan University, Bhubaneswar, Odisha, India. Email: pratapsahu@soauniversity.ac.in

Received: 09 July 2016, Revised and Accepted: 13 July 2016

\section{ABSTRACT}

Objective: To evaluate the nootropic activity of methanolic extract of pre-shodhit and shodhit Semecarpus anacardium (SA) nuts and to observe the effect of shodhana on nootropic activity of SA.

Methods: Spatial learning and working memory was considered for evaluation. The parameters used were spontaneous alternation behavior (Y-maze), number of correct responses (radial maze), and transfer latency in day 1 (elevated plus maze). Scopolamine, an anticholinergic drug, was used to induce cognitive deficit. \% inhibition of acetylcholine esterase (AChE) was measured in vitro.

Results: Both pre-shodhit and shodhit drug reversed the scopolamine-induced a decrease in percentage spontaneous alternation behavior in Y-maze and number of correct responses in radial maze. Scopolamine-induced increase in transfer latency in elevated plus maze was significantly decreased by pre-shodhit drug only. Shodhit drug has no significant effect on transfer latency. Both pre-shodhit and shodhit drug showed dose-dependent inhibition of AChE activity in vitro. Pre-shodhit drug showed a more nootropic activity than shodhit drug.

Conclusion: Methanolic extract of the nuts of $S$. anacardium possesses nootropic activity which may be attributed to inhibition of cholinesterase activity. Shodhana of the nuts decreases nootropic activity.

Keywords: Semecarpus anacardium, Acetylcholine esterase, Shodhana, Nootropic.

(C) 2016 The Authors. Published by Innovare Academic Sciences Pvt Ltd. This is an open access article under the CC BY license (http://creativecommons. org/licenses/by/4. 0/) DOI: http://dx.doi.org/10.22159/ajpcr.2016.v9s2.13989

\section{INTRODUCTION}

Semecarpus anacardium (bhallataka) is categorized as a semipoisonous (Upavisha drabyas) plant in Ayurvedic texts. It has the potential to cause contact dermatitis due to the presence of a chemical called urushiol. Its systemic use leads to toxic symptoms such as skin rashes, burning, itching, excessive thirst, sweating and reduction in urine output with colored urine and sometimes blood in the urine. It is suggested that shodhana (purificatory procedures) of the fruits should be carried out before systemic administration of semi-poisonous plants like bhallataka [1,2]. However, there are no studies on the effect of shodhana on efficacy of the drug.

Methanolic extract of stem bark of $S$. anacardium (SA) shows potent acetylcholine esterase (AChE) inhibitory activity (in vitro). The $\mathrm{IC}_{50}$ value was found to be $16.74 \mu \mathrm{g} / \mathrm{ml}$ [3]. The milk extract of the nuts showed nootropic activity in different animal models [4]. Thorough literature survey does not reveal any study on the effect of shodhana on nootropic activity of SA. Hence, this study is undertaken to evaluate the nootropic activity of methanolic extract of pre-shodhit and shodhit SA nuts and to observe the effect of shodhana on nootropic activity of SA.

\section{METHODS}

Collection, shodhana and preparation of extract

The dried fruits of $S$. anacardium were collected from local market of Bhubaneswar and identified by Dr. Panda, taxonomist, Regional Plant Resource Centre, Bhubaneswar. The thalamus part of the fruit was removed with a steel knife.

Then, the nuts were subjected to fresh cow urine daily for 7 days followed by cow milk (OMFED) daily for 7 days followed by rubbing thoroughly with brick powder for 3 days. During the treatment with cow urine and cow milk, the nuts were washed with water before adding fresh cow urine or milk. On the final day $\left(18^{\text {th }}\right.$ day), the nuts were washed with hot water to remove the brick powder. This shodhana procedure was repeated three times [2].

The nuts were now coarse powdered and $100 \mathrm{~g}$ of the powder was subjected to maceration with methanol (1 L) for $72 \mathrm{hrs}$. The solvent was removed under pressure and the extracts were concentrated under vacuum at $40-60^{\circ} \mathrm{C}$. Similarly, methanol extract of pre-shodhit nuts was also prepared.

\section{Animals}

Wistar albino rats of both sexes (150-200 g) were used in the study. The animals were procured from the animal house of School of Pharmaceutical Sciences, SOA University. They were acclimatized for $48 \mathrm{hrs}$ until the experimentation. They were kept in $12 \mathrm{hrs}$ day-night cycle. Food and water were provided ad libitum. All the experimental protocols were approved by Animal Ethics committee of School of Pharmaceutical Sciences (Regd. No. 1171/C/08/CPCSEA)

\section{Locomotor activity}

The rats were divided into five groups of six animals each. The control group was treated with distilled water $(10 \mathrm{ml} / \mathrm{kg}$ p.o.), whereas Groups II and III were treated with the pre-shodhit drug (PSM) and Groups IV and V were treated with shodhit drug (SM) at a dose of 50 and $100 \mathrm{mg} / \mathrm{kg}$ (p.o.) respectively.

The locomotor activity was studied by Actophotometer (INCO, India). Each animal was placed individually in the activity cage and observed for 10 minutes. The locomotor activity was noted from the digital counter. PSM and SM were compared with control [5-7].

\section{Spontaneous alternation behavior}

The rats were divided into six groups of six animals each. The control group was treated with distilled water $(10 \mathrm{ml} / \mathrm{kg}$ p.o. $)$, whereas Group II was treated with scopolamine ( $2 \mathrm{mg} / \mathrm{kg}$ i.p.). Groups III and IV were treated with pre-shodhit drug (PSM) and Groups V and VI were treated 
with shodhit drug (SM) at a dose of 50 and $100 \mathrm{mg} / \mathrm{kg}$ (p.o.), respectively. Groups III-VI were administered Scopolamine $(2 \mathrm{mg} / \mathrm{kg}$ i.p.) half an hour after administration of the drugs.

Spatial working memory was studied by Y-maze (INCO, India). The animals were individually placed at the center of the Y-maze and allowed to explore for 5 minutes. The successive entries to different arm were observed and expressed as \% alternation [8,9].

Alternation is defined as the number of successive entries into the three arms on overlapping triplet sets. The percentage alteration was calculated as the ratio of actual to possible alternations (defined as the total number of arm entries minus two), multiplied by 100 .

\section{Radial maze}

Spatial working memory was studied by 8 -arm radial maze (INCO, India). The rats were preselected by conducting once daily training trial. A rat was placed on the center of the hub and allowed to enter arms freely. The trial was considered complete when the rat visited all 8 -arms. Then, the rats were divided into six groups of six animals each. The control group was treated with distilled water $(10 \mathrm{ml} / \mathrm{kg}$ p.o. $)$, whereas Group II was treated with scopolamine $(2 \mathrm{mg} / \mathrm{kg}$ i.p.). Groups III and IV were treated with pre-shodhit drug (PSM) and Groups V and VI were treated with shodhit drug (SM) at a dose of 50 and $100 \mathrm{mg} / \mathrm{kg}$ (p.o.), respectively. Groups III-VI were administered scopolamine $(2 \mathrm{mg} / \mathrm{kg}$ i.p.) half an hour after administration of the drugs.

Entry into an arm which the rat had not previously visited was recorded as a correct response and re-entry was counted as an error. The number of correct responses before committing the first error (the number of initial correct responses) was calculated as the index of radial maze performance [10,11].

\section{Elevated plus maze}

Effect on acquisition deficit induced by scopolamine was studied by elevated plus maze (INCO, India). The rats were placed individually at the end of either of the open arms and the time the animal takes to move from open to enclosed arm was noted on the first exposure. This is called transfer latency. The rats were divided into six groups of six animals each. The control group was treated with distilled water $(10 \mathrm{ml} / \mathrm{kg}$ p.o.), whereas Group II was treated with scopolamine ( $2 \mathrm{mg} / \mathrm{kg}$ i.p.). Groups III and IV were treated with pre-shodhit drug (PSM) and Groups V and VI were treated with shodhit drug (SM) at a dose of 50 and $100 \mathrm{mg} / \mathrm{kg}$ (p.o.), respectively. Groups III-VI were administered Scopolamine (2 mg/kg i.p.) half an hour after administration of the drugs. 30 minutes after administration of scopolamine, the transfer latency was noted $[8,12]$.

\section{Acetylcholine esterase assay}

About $150 \mu \mathrm{l}$ of $0.1 \mathrm{M}$ sodium phosphate buffer ( $\mathrm{pH}$ 8.0) was added to $10 \mu \mathrm{l}$ of each test preparations. Then, $20 \mu \mathrm{l}$ enzyme solutions ( 0.1 units $/ \mathrm{ml}$ ) were added followed by 15 minutes incubation at room temperature. $10 \mu \mathrm{l}$ 5,5'-dithio-bis-(2-nitrobenzoic acid) solutions $(10 \mathrm{mM})$ were added to above preparations and the reaction initiated by adding $10 \mu \mathrm{l}$ acetylthiocholine iodide solution $(14 \mathrm{mM})$. After 5 minutes of incubation, the absorbance was measured at $410 \mathrm{~nm}$ against a reagent blank consisting identical preparations except test solution. The AChE inhibition percentage was calculated using equation $[13,14]$ :

$\%$ inhibition of $\mathrm{AChE}=\left[\left(\mathrm{A}_{\text {control }}-\mathrm{A}_{\text {test }}\right) / \mathrm{A}_{\text {control }}\right] \times 100$.

\section{Statistical analysis}

The statistical analyses were performed using One-way ANOVA followed by Dunnet's $t$-test. The statistical analysis of the experimental data was presented as mean \pm SD. $p<0.05$ was considered to be statistically significant in the tests [15].

\section{RESULTS}

\section{Locomotor activity}

Both pre-shodhit and shodhit SA showed no significant change in locomotor activity. The differences in mean were not significant at $\mathrm{p}<0.05$ (Table 1).

\section{Spontaneous alternation behavior}

Scopolamine significantly reduced the spontaneous alternation in Y-maze. Both pre-shodhit and shodhit drug prevented scopolamine induced decrease in spontaneous alternation. However, in the case of shodhit drug, the \% spontaneous alternation behavior significantly $(p<0.05)$ decreased as compared to the pre-shodhit drug (Table 2).

\section{Radial maze}

Scopolamine significantly reduced the number of correct responses in radial maze. Both pre-shodhit and shodhit drug prevented scopolamine induced decrease in number of correct responses. However, in the case of shodhit drug, the number of correct responses significantly $(\mathrm{p}<0.05)$ decreased as compared to pre-shodhit drug (Table 2).

\section{Elevated plus maze}

Scopolamine significantly increased the transfer latency in elevated plus maze. Pre-shodhit drug prevented scopolamine induced increase in transfer latency. However, in the case of shodhit drug $(100 \mathrm{mg} / \mathrm{kg})$, the transfer latency significantly $(\mathrm{p}<0.05)$ increased as compared to pre-shodhit drug (Table 2).

\section{AChE activity}

Both pre-shodhit and shodhit SA showed a dose-dependent increase in $\%$ inhibition of AChE. However, \% inhibition of AChE by shodhit drug significantly decreased $(\mathrm{p}<0.05)$ as compared to the pre-shodhit drug (Table 3).

\section{DISCUSSION}

There are some reports of nootropic activity of S. anacardium [3,4]. This study is undertaken to evaluate the effect of shodhana on nootropic activity of SA. Spatial learning and working memory was considered for evaluation. The parameters used were spontaneous alternation behavior (SAB) (Y-maze), number of correct responses (radial maze), and transfer latency in day 1 (elevated plus maze).

Scopolamine, an anticholinergic drug, was used to induce cognitive deficit. Scopolamine can completely abolish SAB [16]. Decline in cholinergic transmission in the brain hippocampus leads to decline in cognitive function $[12,17]$. Our results are in agreement with these studies.

SAB is a widely used test for evaluation of spatial learning and working memory. Y-maze is popularly used for assessment of SAB $[18,19]$. Many parts of the brain including hippocampus are involved in this task [20]. Hippocampus is crucial for the formation and use of spatial memory. Hippocampal lesions in rodents impair spatial memory on radial arm maze task [11]. The 8-arm radial maze is recognized as an excellent model of spatial memory [21]. Both pre-shodhit and shodhit drug reversed the scopolamine induced decrease in percentage SAB in Y-maze and number of correct responses in radial maze. This justifies the nootropic activity of methanolic extract of $S$. anacardium. However, shodhana decreases the nootropic activity in both the models as there is a significant decrease in \% spontaneous alternation (Y-maze) and number of correct responses (radial maze).

Elevated plus maze is a widely accepted model for study of learning and memory in rodents where decrease in transfer latency (the time elapsed between the movements of an animal from an open area to a closed arm) is related with increased memory function [22]. Transfer latency is used as a parameter to assess consolidation or retrieval mechanisms of learning and memory. However, the treatment of drugs 
Table 1: Effect of methanolic extract of pre-shodhit (PSM) and shodhit (SM) nuts of Semecarpus anacardium on locomotor activity

\begin{tabular}{ll}
\hline Samples dose $(\mathbf{m g} / \mathbf{k g})$ & Locomotor activity $($ mean \pm SD) \\
\hline Control & $60.50 \pm 16.49$ \\
PSM 50 & $45.33 \pm 28.46$ \\
PSM 100 & $42.00 \pm 18.61$ \\
SM 50 & $51.50 \pm 38.24$ \\
SM 100 & $33.33 \pm 17.47$ \\
F $(4,25)$ & 0.98 \\
\hline
\end{tabular}

${ }^{*} \mathrm{p}<0.05, \mathrm{n}=6$. One-way ANOVA followed by Dunnet's $t$-test. Groups II-V are compared with Group I. Groups II and III are compared with Groups IV and V, respectively. SD: Standard deviation

Table 2: Effect of methanolic extract of pre-shodhit (PSM) and shodhit (SM) nuts of Semecarpus anacardium on percentage spontaneous alteration in Y-maze, number of correct responses in radial maze and transfer latency in elevated plus maze

\begin{tabular}{lllll}
\hline Groups & Treatment & \multicolumn{2}{l}{ Mean \pm SD } & \\
\cline { 3 - 5 } & & $\begin{array}{l}\text { Spontaneous } \\
\text { alteration \% }\end{array}$ & $\begin{array}{l}\text { Number } \\
\text { of correct } \\
\text { responses }\end{array}$ & $\begin{array}{l}\text { Transfer } \\
\text { latency }\end{array}$ \\
\hline I & Control & $60.83 \pm 6.91$ & $5.16 \pm 1.16$ & $15.83 \pm 3.06$ \\
II & Scopolamine & $1.83 \pm 2.85^{*}$ & $1.16 \pm 0.41^{*}$ & $275.33 \pm 33.04^{*}$ \\
III & PSM 50 & $57.33 \pm 3.77^{*}$ & $3.33 \pm 0.81^{*}$ & $247.83 \pm 10.96^{*}$ \\
IV & PSM 100 & $64.33 \pm 4.63^{*}$ & $4.16 \pm 0.75^{*}$ & $228.66 \pm 11.44^{*}$ \\
V & SM 50 & $50.83 \pm 4.31^{* \#}$ & $2.16 \pm 0.41^{* \#}$ & $265.83 \pm 11.32$ \\
VI & SM 100 & $37.16 \pm 3.18^{* \#}$ & $2.83 \pm 0.75^{* \#}$ & $267.16 \pm 13.60^{\#}$ \\
& F & $163.52^{*}$ & $13.9^{*}$ & $120.60 *$ \\
\hline
\end{tabular}

${ }^{*} \mathrm{p}<0.05, \mathrm{n}=6$. One-way ANOVA followed by Dunnet's $t$-test. Groups I, III-VI are compared with Group II. " $\mathrm{p}<0.05$ Groups V and VI are compared with Groups II and IV, respectively

Table 3: Effect of methanolic extract of pre-shodhit (PSM) and shodhit (SM) nuts of Semecarpus anacardium on \% inhibition of acetylcholine esterase

\begin{tabular}{llll}
\hline \multirow{2}{*}{ Concentration $(\boldsymbol{\mu g} / \mathbf{m l})$} & \multirow{2}{*}{ Mean \pm value } \\
\cline { 2 - 3 } & PSM & SM & \\
\hline 25 & $67.38 \pm 0.23$ & $17.14 \pm 0.49$ & $224.18^{*}$ \\
50 & $77.50 \pm 0.26$ & $32.49 \pm 1.23$ & $87.39^{*}$ \\
100 & $83.13 \pm 0.42$ & $44.17 \pm 0.46$ & $152.03^{*}$ \\
200 & $86.09 \pm 0.19$ & $58.40 \pm 0.13$ & $283.58^{*}$ \\
\hline
\end{tabular}

${ }^{*} \mathrm{p}<0.05, \mathrm{n}=6$, Student's $t$-test. SM is compared with PSM. SD: Standard deviation

30 minutes before the $1^{\text {st }}$ day exposure may be used for acquisition related action of drugs. Scopolamine produces acquisition deficits [23] The prolongation of transfer latency by scopolamine can be reversed by pretreatment with cholinergic drugs such as physostigmine and tacrine. $[24,25]$. In this study, Scopolamine-induced increase in transfer latency in elevated plus maze was significantly decreased by preshodhit drug only. Shodhit drug has no significant effect on acquisition deficit caused by scopolamine. However, the improvement in acquisition deficit was significantly decreased by shodhana.

Acetylcholine plays a main role in cholinergic transmission in brain especially hippocampus and involved in spatial memory performance. $\mathrm{ACh}$ is degraded by AChE enzyme. Hence, a drug which inhibits AChE enzyme can increase cholinergic function and improve memory [26,27] In this study, both pre-shodhit and shodhit drug showed dose-dependent inhibition of AChE activity in vitro. Again, there is a decrease in \% inhibition of AChE activity by shodhit drug which suggests a decrease in cholinergic function. So decrease in nootropic activity of shodhit SA may be attributed to decreased cholinergic function.
Shodhana is a method of purification. It is usually used to remove the poisonous substances from the plants or plant parts. However, in this process, there may be removal of some useful chemicals. In this study, shodhana might have removed some anticholinesterase principles.

\section{CONCLUSION}

Methanolic extract of the nuts of $S$. anacardium possesses nootropic activity. This nootropic activity may be attributed to its anticholinesterase activity. Shodhana of the nuts decreases nootropic activity.

\section{REFERENCES}

1. Raut AK, Sawant NS, Badre AS, Amonkar AA, Vaidya DB. Bhallataka (Semecarpus anacardium Linn) - A review. Indian J Trad Knowl 2007;6(4):653-9.

2. Ilanchezhian R, Acharya RN, Roshy JC, Shukla VJ. Impact of Ayurvedic Shodhana (purificatory procedures) on Bhallataka fruits (Semecarpus anacardium Linn) by measuring the anacardol content. GJRMI 2012;1(7):286-94

3. Vinutha B, Prashanth D, Salma K, Sreeja SL, Pratiti D, Padmaja R, et al. Screening of selected Indian medicinal plants for acetylcholinesterase inhibitory activity. J Ethnopharmacol 2007;109(2):359-63.

4. Farooq SM, Alla TR, Rao NV, Prasad K, Shalam K, Satyanarayana SA Study on CNS effect of nut milk extract of semecarpus anacardium. Pharmacologyonline 2007;1:49-63.

5. Bhattacharya A, Naik MR, Agrawal D, Sahu PK, Kumar S, Mishra SS CNS depressant and muscle relaxant effect of ethanolic leaf extract of Moringa oleifera on albino rats. Intern $\mathrm{J}$ Pharm Tech Res 2014;6:1441-9.

6. Pal A, Nayak S, Sahu PK, Swain T. Piperine protects epilepsy associated depression: A study on role of monoamines. Eur Rev Med Pharmacol Sci 2011;15(11):1288-95.

7. Pany SK, Pal A, Sahu PK. Neuroprotective effect of quercetin in neurotoxicity induced rats: Role of neuroinflammation in neurodegeneration. Asian J Pharm Clin Res 2014;7(4):410-2.

8. Pal A, Sahu PK, Swain T, Juadi S. Effect of galanolactone on learning and memory: A study on role of serotonin. Pharmacologyonline 2010;3:102-11

9. Shahid M, Pillai KK, Vohora D. Reversal of phenytoin induced impairment of spontaneous alteration by piracetam in mice: Involvemen of cholinergic system. Indian J Pharmacol 2004;36(1):20-4.

10. Eckerman DA, Gordon WA, Edwards JD, MacPhail RC, Gage MI Effects of scopolamine, pentobarbital, and amphetamine on radial arm maze performance in the rat. Pharmacol Biochem Behav 1980;12(4):595-602.

11. Goodrich-Hunsaker NJ, Hopkins RO. Spatial memory deficits in a virtual radial arm maze in amnesic participants with hippocampal damage. Behav Neurosci 2010;124(3):405-13.

12. Sharma AC, Kulkarni SK. Reversal of Scopolamine and Dizocilpine induced memory dysfunction by angiotensin converting enzyme inhibitors in rats \& mice. Indian J Pharmacol 1992;24:147-53.

13. Ellman GL, Courtney KD, Andres V Jr, Feather-Stone RM. A new and rapid colorimetric determination of acetylcholinesterase activity. Biochem Pharmacol 1961;7:88-95.

14. Hasnat MA, Pervin M, Lim BO. Acetylcholineserase inhibition and in vitro and in vivo antioxidant activities of Ganoderma lucidum grown on germinated brown rice. Molecules 2013;18: 6663-78.

15. Kulkarni SK. Handbook of Experimental Pharmacology. $3^{\text {rd }}$ ed. New Delhi: Vallabh Prakashan; 1999. p. 172-89.

16. Douglas RJ, Isaacsoo RL. Spontaneous alternation and scopolamine. Psychol Sci 1966;4:283-4.

17. Spencer DG Jr, Lal H. Effects of anticholinergic drugs on learning \& memory. Drug Dev Res 1983;3:489-502.

18. Hooper N, Fraser C, Stone TW. Effects of purine analogues on spontaneous alternation in mice. Psychopharmacology (Berl) 1996;123:250-7.

19. Hughes RN. The value of spontaneous alternation behavior (SAB) as a test of retention in pharmacological investigations of memory. Neurosci Biobehav Rev 2004;28:497-505

20. Madhavadas S, Subramanian S. Combination of Spirulina with glycyrrhizin prevents cognitive dysfunction in aged obese rats. Indian J Pharmacol 2015;47:39-44.

21. Hao D, Yang L, Chen S, Tian Y, Wu S 916 MHz electromagnetic field exposure affects rat behavior and hippocampal neuronal discharge. 
Neural Regen Res 2012;7:1488-92.

22. Achliya G, Barabde U, Wadodkar S, Dorle A. Effect of Brahmi Ghrita, a polyherbal formulation on learning and memory paradigms in experimental animals. Indian J Pharmacol 2004;36:159-62.

23. Sharma AC, Kulkarni SK. Evaluation of learning and memory mechanisms employing elevated plus-maze in rats and mice. Prog Neuropsychopharmacol Biol Psychiatry 1992;16:117-25.

24. Itoh J, Nabeshima T, Kameyama T. Utility of an elevated plusmaze for the evaluation of memory in mice: Effects of nootropics, scopolamine and electroconvulsive shock. Psychopharmacology (Berl)
1990;101:27-33.

25. Saini D, Dhingra AK, Chopra B, Parle M. Psychopharmacological investigation of the nootropic potential of Trigonella foenum Linn in mice. Asian J Pharm Clin Res 2011;4:76-84.

26. Kulkarni PD, Ghaisas MM, Chivate ND, Sankpal PS. Memory enhancing activity of Cissampelos pariera in mice. Int J Pharm Pharm Sci 2011;3:206-11.

27. Kukkar MR, Saluja AK, Sachdeva PD, Kukkar RR. In vivo investigation of the neuroprotective potential of Cardiospermum halicacabum Linn. Int J Pharm Pharm Sci 2014;6:64-6. 